\section{NRC releases report
on energy efficiency in autos by 2050}

www.nap.edu
T he National Research Council finds that by the year 2050, the United States may be able to reduce petroleum consumption and greenhouse gas emissions by $80 \%$ for cars and small trucks through a combination of more efficient vehicles; the use of alternative fuels like biofuels, electricity, and hydrogen; and strong government policies to overcome high costs and influence consumer choices. While achieving these goals will be difficult, improving technologies driven by strong and effective policies could make deep reductions possible. The Council details its findings in the report, "Transitions to Alternative Vehicles and Fuels."

"To reach the 2050 goals for reducing petroleum use and greenhouse gases, vehicles must become dramatically more efficient, regardless of how they are powered," says Douglas M. Chapin, principal of MPR Associates, and chair of the committee that wrote the report.

Improving the efficiency of conventional vehicles is, up to a point, the most economical and easiest-to-implement approach to saving fuel and lowering emissions, the report says. This approach includes reducing the work the engine must perform - reducing vehicle weight, aerodynamic resistance, rolling resistance, and accessories - plus improving the efficiency of the internal-combustion engine powertrain.

Improved efficiency alone will not meet the 2050 goals, however. The average fuel economy of vehicles on the road would have to exceed $180 \mathrm{mpg}$, which, the report says, is extremely unlikely with current technologies. Therefore, the study committee also considered other alternatives for vehicles and fuels, including hybrid electric vehicles, plug-in hybrid electric vehicles, battery electric vehicles, hydrogen fuel-cell electric vehicles, and compressed natural-gas vehicles.
Although driving costs per mile will be lower, especially for vehicles powered by natural gas or electricity, the high initial purchase cost is likely to be a significant barrier to widespread consumer acceptance, the report says. Additionally, particularly in the early years, the report predicts that some of the alternative vehicles will rely on fuels that are not readily available or have restricted travel range, and others may require bulky energy storage that will limit their cargo and passenger capacity. Strong policies and technology advances are critical in overcoming these challenges.

The report identified several scenarios that could meet the more demanding 2050 greenhouse gas goal. Each combines highly efficient vehicles with at least one of three alternative power sourcesbiofuels, electricity, or hydrogen. While corn-grain ethanol and biodiesel are the only biofuels to have been produced in commercial quantities in the United States to date, the study committee found much greater potential in biofuels made from lignocellulosic biomass, which includes crop residues like wheat straw, switch grass, whole trees, and wood waste. This "drop-in" fuel is designed to be a direct replacement for gasoline and could lead to large reductions in both petroleum use and greenhouse gas emissions; it can also be introduced without major changes in fuel delivery infrastructure or vehicles. The report finds that sufficient lignocellulosic biomass could be produced by 2050 to meet the goal of an $80 \%$ reduction in petroleum use when combined with highly efficient vehicles.

Vehicles powered by electricity will not emit any greenhouse gases, but the production of electricity and the additional load on the electric power grid are factors that must be considered. To the extent that fossil resources are used to

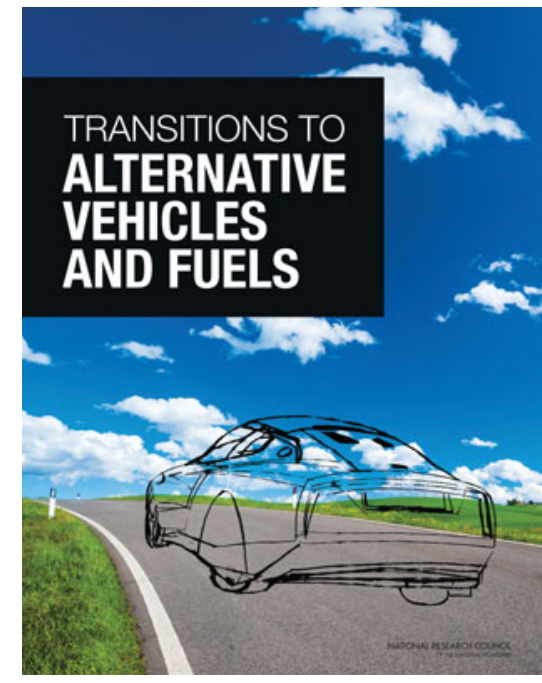

Courtesy of the National Research Council

generate electricity, the report says that the successful implementation of carbon capture and storage will be essential. These vehicles also rely on batteries, which are projected to drop steeply in price. However, the report says that limited range and long recharge times are likely to limit the use of all-electric vehicles mainly to local driving. Advanced battery technologies under development all face serious technical challenges.

When hydrogen is used in fuel cells in electric vehicles, the only vehicle emission is water. However, varying amounts of greenhouse gases are emitted during hydrogen production, and the low-greenhouse gas methods of making hydrogen are more expensive and will need further development to become competitive. Hydrogen fuel-cell vehicles could become less costly than the advanced internal-combustion engine vehicles of 2050. Fuel-cell vehicles are not subject to the limitations of battery vehicles, but developing a hydrogen infrastructure in concert with a growing number of fuel-cell vehicles will be difficult and expensive, the report says.

The technology advances required to meet the 2050 goals are challenging and not assured. Nevertheless, the committee considers that dramatic cost reduction and overall performance enhancement is possible without unpredictable technology breakthroughs. Achieving these goals 
requires that the improved technology focus on reducing fuel use rather than adding greater power or weight, the report says.

Overcoming the barriers to advanced vehicles and fuels will require a rigorous policy framework that is more stringent than the proposed fuel economy standards for 2025. This policy intervention could include high and increasing fuel economy standards, R\&D support, subsidies, and public information programs aimed at improving consumers' familiarity with the new fuels and powertrains. Because of the high level of uncertainty in the pace and scale of technology advances, this framework should be modified as technologies develop and as conditions change, says the report.
It is essential that policies promoting particular technologies to the public are not introduced before these new fuels and vehicle technologies are close to market readiness, and consumer behavior toward them is well understood. The report warns that forcing a technology into the market should be undertaken only when the benefits of the proposed support justify its costs
IEA and WBCSD announce technology roadmap for Indian cement industry www.wbcsdcement.org/india-tech-roadmap

I ndia's fast-growing cement industry can reduce its carbon emissions by nearly half by the middle of the century, according to a technology roadmap issued in February by the International Energy Agency (IEA) and the World Business Council for Sustainable Development (WBCSD).

Faced with massive infrastructure and housing requirements, India is the world's fastest growing cement market - and will likely remain in that position for the foreseeable future. The report, "Technology Roadmap: Low-Carbon Technology for the Indian Cement Industry," outlines a way for the Indian cement industry to reduce its $\mathrm{CO}_{2}$ emissions by 2050 by at least 210 $\mathrm{MtCO}_{2}$ compared to a business-as-usual scenario. The savings roughly equal the total $\mathrm{CO}_{2}$ emissions of Thailand in 2009. This transition will also have energy benefits, reducing energy consumption by at least $275 \mathrm{PJ}$ - which is as much as the current industry energy consumption of Singapore, Norway, or the Philippines.

According to IEA and WBCSD, the Indian cement industry is among the most efficient in the world and has made strong efforts to reduce its carbon footprint. Yet, opportunities for improvements still exist. The milestones set out in this roadmap would enhance the country's energy security by limiting the growth in energy consumption, and would further reduce the direct $\mathrm{CO}_{2}$ emissions intensity by about $45 \%$ from current levels by 2050 , according to the report.

The International Finance Corporation (IFC), which is a member of the World Bank Group and is focused exclusively on the private sector in developing countries, will provide financial support for the next step to be taken by the Indian cement companies that are members of WBCSD's Cement Sustainability Initiative (CSI). In this step, known as Phase II, Indian CSI member companies will carry out a detailed feasibility study of low-carbon technology implementation at one specific plant per company. Then, through the CSI network, lessons learned will be shared with the wider cement industry in India and abroad. The assessment will identify specific areas where investments in energy efficiency, technology up-gradation, and material conservation can lead to reduction in greenhouse gas emissions.

T. Kumar, Joint Secretary of the Department of Industrial Policy and Promotion within the Indian Ministry of Commerce and Industry, says, "I am happy to note that industry has already achieved 36\% reduction in $\mathrm{CO}_{2}$ emissions. With depleting limestone reserves, newer materials and newer technologies are needed for India's infrastructure development." The government has plans for infrastructure development in the next five years.

Among the recommendations of the report are policies to support research and development (R\&D). "For example," said the report, "a new generation of hydraulic binders could provide high emissions reduction, but this technology is not yet well understood or developed at scale, and needs further R\&D.” The report calls for the funding and expansion of new areas of research, such as in the comminution area, a process in which solid materials are reduced in size or in which useful materials are freed from embedded matrix materials. The report also pointed out the need for R\&D on "the use of nano-particles to reinforce cementitious materials for improved flexibility and toughness," while simultaneously taking into account studies on the safety of nanoparticles in cement manufacturing.

In order to enable the cement industry to implement steps detailed in the roadmap, the report includes a roadmap action plan. Among these actions, the Ministry of Commerce and Industry is to allocate good quality linkage coal to the cement industry to maximize the life of Indian limestone deposits. The Bureau of Indian Standards is to develop standards and implement regulation for clinker substitutes. For the development and deployment of new transformational technologies, the Ministry of Finance is to sustain funding and the Ministry of Science and Technology is to put into place a support mechanism.

In further action plans, academic and research institutions as well as equipment manufacturers are to conduct $R \& D$ on "fuel cells and large-scale adoption of futuristic comminution technologies" and "carbon capture and storage to help industry move through pilot to demonstration phase to widespread implementation."

The roadmap development was spearheaded by the three co-chair companies, ACC, Shree Cement, and UltraTech, who committed extensive resources and expertise from across their companies to lead the project. They were supported by a wider working group from the other CSI companies in India. The initiative, supported by IFC, was developed in collaboration with the Confederation of Indian Industry (CII) and the National Council for Cement and Building Materials (NCB). 